\title{
我が国のオフイス照明環境と執務者評価の変遷に関する研究 \\ A STUDY ON THE CHANGES OF LIGHT ENVIRONMENT AND EVALUATIONS BY WORKERS IN JAPANESE OFFICE
}

\author{
成島雄一*1, 宗方 淳*2, 岩田利枝*3, 谷口智子*4, 望月悦子*5 \\ Yuichi NARISHIMA, Jun MUNAKATA, Toshie IWATA, \\ Tomoko TANIGUCHI and Etsuko MOCHIZUKI
}

\begin{abstract}
This study explores the transition of illuminance of Japanese office environment as well as subjective evaluation toward brightness by reviewing existing scientific literatures of over half century. In total 484 data of illuminance of actual office and 28 literatures which studied the relation of lighting environment and subjective evaluation were extracted. In the last over half century, the illuminance of office environment have been increasing along with the recommended level of illuminance of JIS. Before 1980s, the actual illuminance level of Japanese office was higher than the recommended level of JIS, and then it became to be settled on or less than the recommended level of JIS standard. The subjective evaluation of illuminance also have been changing since 1950s. Before 1970s, people satisfied lighting environment less than $300 \mathrm{~lx}$, and people became to be unsatisfied of $300 \mathrm{~lx}$ after 1980s. On the other hand, illuminance level of $750 \mathrm{~lx}$ has been evaluated positive consistently since 1970s.
\end{abstract}

Keywords : Literature review, Lighting Environment of Japanese Office, Subjective Evaluations, Transition, Illuminance 文献調查，オフィス照明環境，主観評価，変遷，照度

\section{1 はじめに}

\section{1-1 研究の背景・目的}

2011 年 3 月に発生した東日本大震災を契機とする原子力発電所 の停止に伴い、我が国におけるオフィスビルでの省エネルギーはま すます重要性を増してきた。オフィスビルにおける消費エネルギー

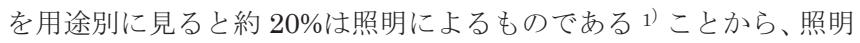
用エネルギー削減の為す役割は大きい。オフィスの照明消費電力量 は設定照度、器具の発光効率や照明率・保守率、照明寸る面積と点 灯時間で決まるとされているため、設定照度を下げることは効果が 大きいと考えられる。現在のオフィス照明設計の基準には、JIS Z 9110:2011による照明基準総則（以下、JIS照度基準と呼ぶ）と 1972 年制定の事務所衛生基準規則とが存在しており、それぞれで規定さ れている事務所の照度の值は異なっているが、後者は建築物として 満たすべき最低限の照度を規定しているものであり、前者の方が高 い基準值を規定している。JIS 照度基準は 1953 年制定の屋内照明 基準を前身とし、「人々の諸活動が、安全、容易、かつ、快適に行え るための照明設計基準及び照明用件の総則」2) として 1958 年に制 定された。中村らによると、同基準は制定以降徐々に推奨照度の值
を上げており、CIE29.2 において規定されたオフィス照度の代表值 $500 \mathrm{~lx}$ と比較しても、日本の推奨照度 750lx は高照度であり、良否 を再検討す心゙きであると主張している ${ }^{3)}$

JIS 照度基準の上昇の理由については、新光源の開発や電気料金 の相対的減少がまず考えられる。1970 年前後に約 $801 \mathrm{~m} / \mathrm{W}$ であっ た $40 \mathrm{~W}$ 直管形蛍光ランプの発光効率は、 3 波長形蛍光ランプやイン バーター式蛍光ランプなどの開発により 2010 年には約 $1001 \mathrm{~m} / \mathrm{W} に$ なり、同じ消費電力でも 1.25 倍の光束を得られるようになった ${ }^{4}$ 。 また、電気料金は 1958 年には現代の価值で $1 \mathrm{~kW}$ あたり 111 円だっ たが、2012 年には 18 円に值下がりしており5)6)、ハード、コスト 両面を考慮しても高照度環境を容易に実現できるようになった。一 方で、経済や社会の発展に伴って生活水準が上がり、利用者からの 要求の高まりが結果的に実際の照度を上げた可能性もある。そして 高照度環境がいわば「当たり前」になったことで、それに引っ張ら れる形でJIS 照度基準も上昇したと考えられる。

今後も光源の改善や社会の変化に伴い、人々がより明るさを求め ていく可能性は否定できない。しかし、宗方は東日本大震災の前後 でのオフィス光環境評価を比較し、震災後という特殊な条件下では
*1 旭化成ホームズ株) 修士 (工学)、（元千葉大学大学院生

*2 千葉大学大学院工学研究科 教授・博士 (工学)

*3 東海大学工学部 教授. 博士 (工学)

*4 東海大学大学院総合理工学研究科 博士課程 $\cdot$ 修士 (工学)

*5 千葉工業大学工学部 教授・博士 (工学)
Asahi Kasei Homes Co./Former Grad Stud Chiba Univ, MEng.

Prof., Grad. Sch. of Eng., Chiba Univ., Dr.Eng.

Prof., Fac. of Eng., Tokai University, Dr.Eng.

Grad. Sch. of Sci. and Tech., Tokai Univ., M.Eng.

Prof., Fac. of Eng., Chiba Inst. of Tech., Dr.Eng. 
あるが「やや暗すぎる」という明るさでも「満足」側の回答をする 執務者が震災前よりも増加寸ることを示した 7)。また、加納らは震 災直後から 2013 年まで継続して節電対策がとられているオフィス でのアンケート調查より、執務者の節電照明への慣れを示唆した上 で、空間が明るいほど満足度が高くなるわけではないことを確認し ており 8)、現在の社会的背景を鑑みると、要求する照度が必ずしも 上り続けるとはいえない。

そこで本研究では、照度基準制定以降に竣工したオフィスの照度 の変遷と、執務者の照明環境、特に照度に対する評価の変遷に着目 し、文献調查によりこれら 2 点の変遷を追い、今後の照明環境のあ り方を再考するための基礎的な知見を得ることを目的とする。なお、 執務者の照度に対する評価の変遷については、過去に行われたオフ イス実態調查・実験の中から執務者の明るさに対する評価に直接言 及している事例を収集する。このように過去の研究からデータを読 み取るという研究手法は多くの先行研究があり 911011112) その有効性 は認められているため、本研究でもその手法を踏襲する。

\section{2 オフィス照度の変遷}

\section{2-1 調査方法}

照度基準制定以降のオフィス照度の変遷を追っていくため、JIS 照度基準の前身である屋内照明基準の制定された 1953 年から 2013 年までに実際に竣工した 484 事例の照度データを文献調查より収集 した。調查対象の文献は建築設備士技術者協会出版の建築設備士 1985 年第 12 号から 2013 年第 9 号、照明学会出版の新編照明のデ ータブック、照明学会誌 1954 年 10 月号から 2013 年 9 月号の計 3 誌であった注1)。各年における収集事例数を表 1 に示す。同じ建物内 でも複数の室が掲載されていた場合、1 室を 1 事例として扱った。 なお、掲載事例は竣工年の記載があるものとないものとがあるため、 事例数は文献への掲載年として統一した。掲載年と竣工年の双方の 記述のあるデータ 338 件を見ると、掲載年が竣工年に対して 1 年遅 れているものが 186 件で最も多く、平均して 1.08 年のずれがある。

\section{表 1 各年代における照度データ収集事例数}

\begin{tabular}{|c|c|c|c|c|c|c|c|c|}
\hline 年 & 1950 年代 & 1960 年代 & 1970 年代 & 1980年代 & 1990年代 & 2000年代 & 2010年代 & 合計 \\
\hline 件数 & 32 & 76 & 62 & 49 & 89 & 104 & 72 & 484 \\
\hline
\end{tabular}

各文献に記載されている照度データは、設計值の場合と実測值の 場合など、事例により掲載方法が異なっていたが、全て「照度」と して統一して読み取った注2)。事例によっては○○〜○○Ixのように 照度幅で掲載されていたが、その場合は照度範囲の中央值を代表值 として扱った。

\section{2-2 調査結果}

文献より読み取った各年における事例の照度の中央值と $25 \%$ 、 $75 \%$ そぞれのパーセンタイル值を図 1 に示す。図 1 には屋内照明 基準、JIS 照度基準で制定されている照度の基準範囲注3) と推奨照度 (以下、それぞれ JIS 照度基準範囲と JIS 推奨照度と記す)も示した。 なお、JIS Z 9110-2010については、追補の範囲で示している。1953 年から 1957 年にかけては、竣工事例の照度の中央值が最も低くて 1955 年の $2001 x$ となり、いずれの年でも JIS 照度基準範囲よりも 高照度である 2001x 以上となっている。その後 1958 年に JIS 照度
基準が制定され、1964 年まで JIS 照度基準範囲が 150～3001x とな ったが、ここでも照度はJIS 照度基準範囲よりも高い。1964 年に 2 度目の JIS 照度基準の改正が行われ、JIS 照度基準範囲は 300〜 $7001 \mathrm{x}$ まで上昇したが、1979 年までの 15 年中、10 年は照度の中央 值が JIS 照度基準範囲よりも高い值となっていた。また、1964 年 から 1976 年までの照度の中央值に着目すると、2011 年以降の JIS 照度基準範囲の上限である $10001 \mathrm{x}$ 付近の值となっており、現在の JIS 照度基準と比べても高照度であったことがわかる。一方で、1979 年の 5 度目の改正で JIS 照度基準範囲が 300〜 750lx になったのを 境に、JIS 照度基準範囲に照度が収まることが増え始める。1979 年 から 2013 年までの 35 年間を見ると、照度の中央值が JIS 照度基準 範囲を上回ったのは 1979 年、1983 年、1989 年の 3 度のみである。 75 パーセンタイル值も、JIS 照度基準範囲を上回ったのは 7 度のみ であった。しかし、1994 年以降は全ての年で中央值が $6001 \mathrm{x}$ を上回 っており、2009 年までの JIS 推奨照度であった 500lx よりも $100 \mathrm{~lx}$ 以上高い水準を維持し続けていた。その後、2010 年に JIS 推奨照 度は 500lx から 750lx に上昇した。また、2010 年から 2013 年にか けては、中央值、パーセンタイル值がいずれも同じ值を維持してい るが、全ての年で JIS 推奨照度の 750lx 以下の值となっている。照 度の中央值が JIS 推奨照度以下となるのは 2010 年以降の 4 年間の みであった。注4)

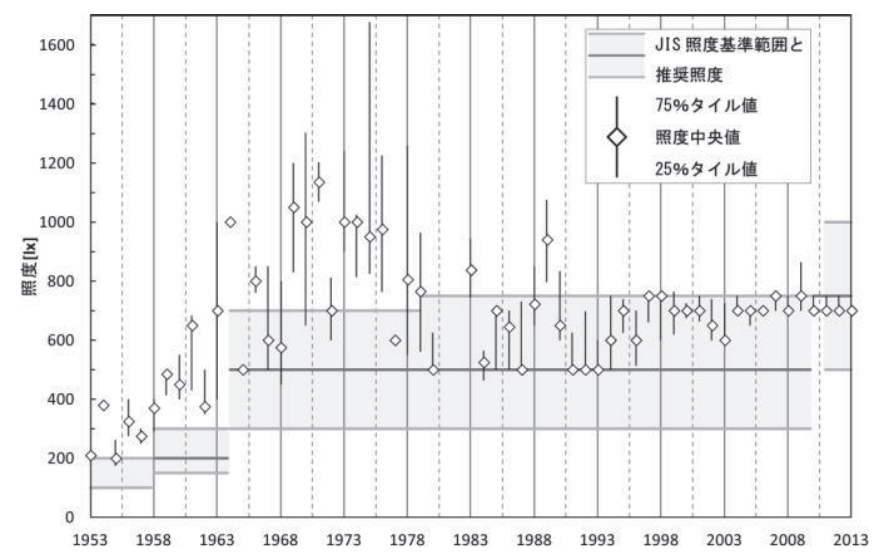

図 1 各年の照度中央值・パーセンタイル值と JIS 照度基準

\section{2-3 考察}

484 事例の照度データを収集し、その変遷を整理すると、掲載年 と竣工・測定年とで 1 年程度の差はあるものの、照度の実態は大き く分けて以下の 4 つに分類されることがわかった。

1）期：1953〜1963 年

屋内照明基準制定から 1964 年の JIS 照度基準改正の直前まで。 照度が当時の JIS 照度基準範囲を上回っていた。

2) II 期：1964〜1979 年

JIS 照度基準值が 300〜 700lx であった頃。現在と比べても高照 度の時代が続いていた。

3) III期：1982１993 年

JIS 照度基準值は 300〜 750lx。 II 期に比べて照度が低下し、JIS 照度基準範囲に収まるようになる。しかし 75 パーセンタイル值が JIS 照度基準範囲以上になることもあった。

4)IV期：1994～2013 年 
この間に JIS 照度基準は 2 回改正が行われ、2010 年には推奨照 度のみの 7501x になった。いずれの年も照度の中央值は 600 7501x の間で推移しており、75 パーセンタイル值を含めてもほとんどの年 で照度は JIS 照度基準範囲に収まっている。また、2011 年以降 JIS 照度基準範囲に含まれるようになった 750〜 1000lx のオフィスは、 今回の調查範囲にはなかった。

全体を通して見ると、I 期、II 期では照度は基準を上回っており 1000lx以上の高照度が散見されたが、III、IV期になるにつれ徐々に 低下した。また、1965年の文献に「日本工業規格JISZ9110-1964の 改正で、一般事務室の標準照度が5001xに大幅に引き上げられたが、 この照度は従来でも寸でに設計上採用されていた值で、高出力けい 光灯の普及とともにますます高照度の傾向である」とある13)ことか ら、高出力蛍光ランプの使用開始による照度上昇に引き上げられる 形で1964年にJIS照度基準が急激に上昇したと考えられる。

一方で、III期に急激に照度が低くなったのは、1970年代後半の石 油危機の影響や、オフィスのOA化でCRT画面への映りこみを避け るための器具発光面の低輝度化の影響で低照度化されたため15)であ ると考えられる。事例ごとの照度が7001x前後に収束した IV 期にお いては、II 期、III期と比較してパーセンタイル值のばらつきが少な くなり、ほぼJIS照度基準の範囲内に収まっていることから、多く のオフィスはJIS照度基準に合わせて設計が行われたと考えられる。 一方で、IV期においては照度の中央值がほとんどの年で2009年まで のJIS推奨照度である5001xより1001x以上高い。2010年にJIS照度基 準は推奨值のみの $750 \mathrm{~lx} に 上$ 昇したが、実際のオフィスの照度はこ れに先行する形で上昇したといえる。全ての年に言えることだが、 75パーセンタイル値を含む照度はいずれもJIS照度基準の範囲内か、 それを上回る值となっており、どの事例も少なくともJIS照度基準 を満たしていた。

\section{3 オフィス執務者意識の変遷}

\section{3-1 調查方法}

\section{(1)調査対象}

続いて、オフィスの照明環境の変化によって執務者の明るさへの 評価にも変化があったのかを確認するため、文献調查を行った。調 查対象は、2 章と同じく屋内照明基準が制定された 1953 年から 2013 年までに発表された研究論文である。実際のオフィスでの実態調査 と、オフィスを想定した空間での印象評価実験の事例を収集した。 収集にあたっては、(1)オフィスで行われた実態調查または実験であ ること、(2)オフィスを想定した空間における実態調查または実験で あること、(3)文献内に照度の記載があること、(4)文献内に一定の照 度に対する執務者の評価に直接言及寸る記載があること、(5)人工照 明の基準の再検討に用いる知見を得るという目的上、昼光の影響の ない条件下での実態調查・実験であること、という5 点を全て満た していることを条件とした。調查対象の文献は(社)照明学会の会誌 及び全国大会講演論文集、日本建築学会の論文集及び大会の学術講 演梗概集とした。日本建築学会出版物からの文献収集については、 一般社団法人日本建築学会ホームページ(http://www.aij.or.jp/)の 「論文集・会誌」より『照度』、『オフィス』、『評価』、『事務所』、『調 查』、『アンケート』、『光環境』、『満足度』をキーワードとしてそれ ぞれ検索をかけ、得られた検索結果の中から収集基準に該当する文
献を調べるという方法で収集した。

\section{(2)グラフの作製}

照明学会の出版物より 15 件、日本建築学会大会学術講演梗概集 より 13 件、合計 28 件の事例を収集した。収集した事例より、照度 と執務者の評価を対応させているデータを 32 件抽出しグラフを作 成、横軸照度、縦軸評価項目で統一して配置した図を作成した。作 製したグラフの一例を図 2 に示す。

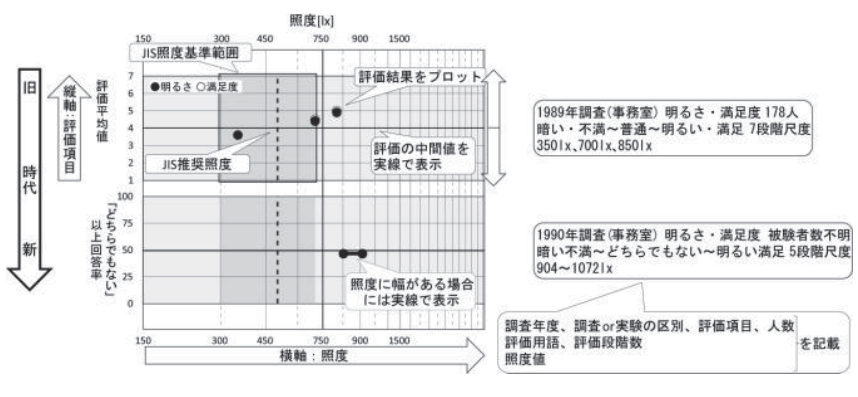

図 2 グラフの表記

グラフの横軸である照度は、差異を明確にするため、対数軸で表 記し 150〜3200lx の範囲に統一した。収集したデータの中には 150lx 以下という低照度のものもあったが、事務所衛生基準規則で 規定された普通の照度は $1501 \mathrm{x}$ 以上とされており、現実的には $1501 \mathrm{x}$ という低照度のオフィスは考えにくいため、今回は除外した。また、 JIS 照度基準との対応を明確にするため、各年における JIS 照度基 準の範囲を濃い灰色で、JIS 推奨照度を破線で、それぞれグラフ上 に記載してある。現在の JIS 推奨照度である 7501x は黒い実線でグ ラフ上に記載した。データに記載されていた照度に幅がある場合、 グラフ中には照度の最大值と最小值を示したマーカーを実線で結ん で表示した。グラフの縦軸は評価項目とした。評価項目は「明るさ」、 「満足度」、「暗さの気になり」など多岐に渡るものであったが、ど れも執務者の照度に対する要求を反映しているものであるため、同 一の形式でグラフを作成してある。それぞれの評価項目はグラフ左 側の軸名に記載してある。また、評価項目は 7 段階評価等のカテゴ リー評価の平均値の場合と、執務者の回答率の場合がある。前者の 場合は、全被験者のカテゴリー評価の平均值をプロットした。後者 の場合は、「どちらでもない」の回答を含めた「良い」側の評価を した人数の割合をプロットした。図 2 の場合、上のグラフが段階評 価の平均值を示したもの、下のグラフが明るさ・満足度について「ど ちらでもない以上の回答をした執務者の割合を示したものである。 評価の差異を明確にするため、5 段階や 7 段階評価といった段階評 価の中間值(または回答割合 $50 \%$ のライン)は黒い実線で各グラフに 示した。各グラフ中には、データが得られた事例の発表年、実測調 査または実験の区別、評価項目、回答者の人数、評価用語、評価力 テゴリー数、照度值を補足として記載した。

このように同一の形式のグラフを 32 個作製注 5)し、発表年の古い ものは上、新しいものは下になるように時系列で配置した。同一の 事例中に複数の評価項目があり、グラフを複数作製した場合は、そ れらのグラフを破線の枠で括った。グラフを作成した元の文献は、 評価項目の上に片括弧付きで参考文献番号を記載した。結果を図 $3 、$ $4 、 5 、 6$ に示す。 


\section{3-2 調査結果}

本調査における評価では、各年における照度への評価が 5 段階や 7 段階評価の中間値(または回答割合 $50 \%$ )以上だった場合、「肯定 側」の評価、中間值未満だった場合「否定側」の評価と定義した。 ここでは、1958 年の JIS 照度基準制定時の上限值(以下、JIS 上限 值と記す)であった $300 \mathrm{~lx} 、 J I S$ 推奨照度として採用されたことのあ る 500lx、750lx 付近の照度での評価について変遷を見ていく。

1)3001xに関して

まず、1958 年から 1963 年までは JIS 上限值、1964 年から 2009 年までは JIS 照度基準下限值(以下、JIS 下限値と記す)であった 300lx 付近の照度に着目する。1955 年の文献 15)では、3131x で $86.5 \%$ の々が肯定側の評価をしている。

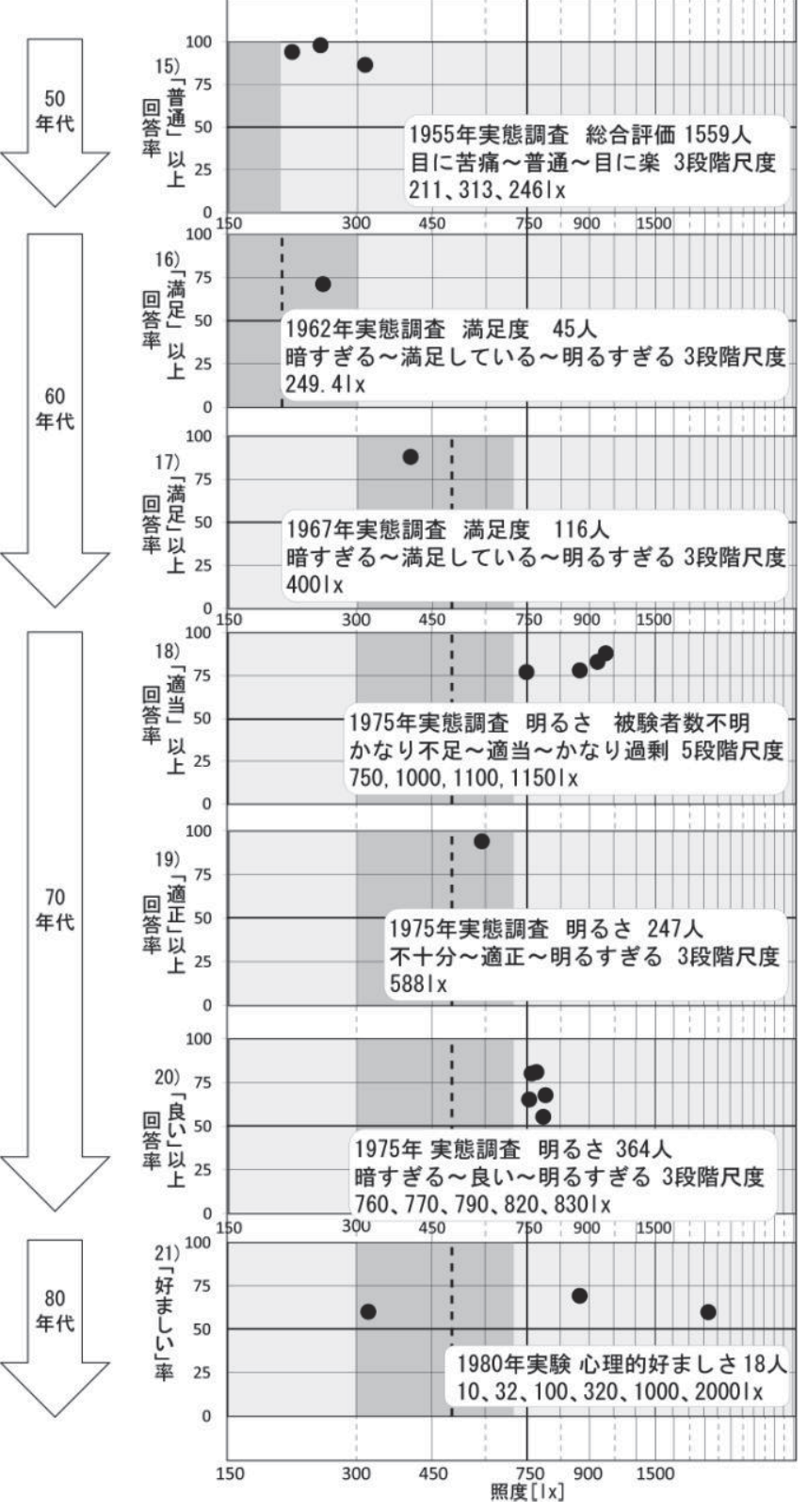

図 3 各研究結果の年代別比較 (1955 1980)
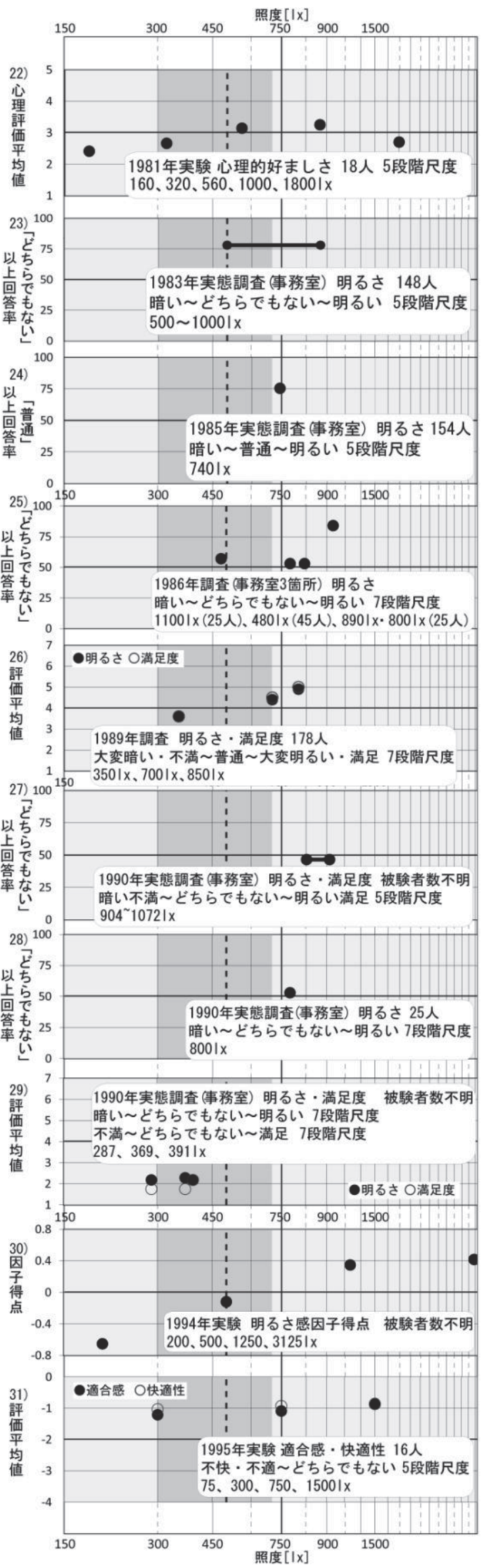

図 4 各研究結果の年代別比較 (1981 1995) 


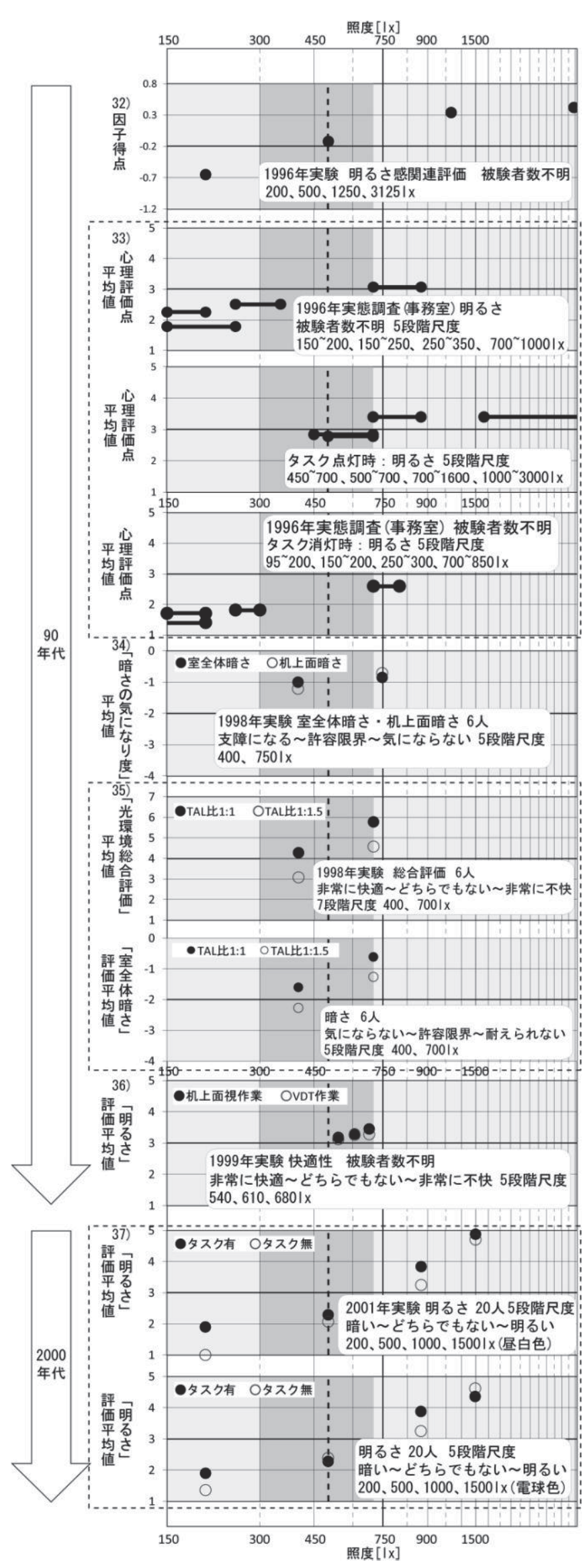

図 5 各研究結果の年代別比較 (1996 2001)

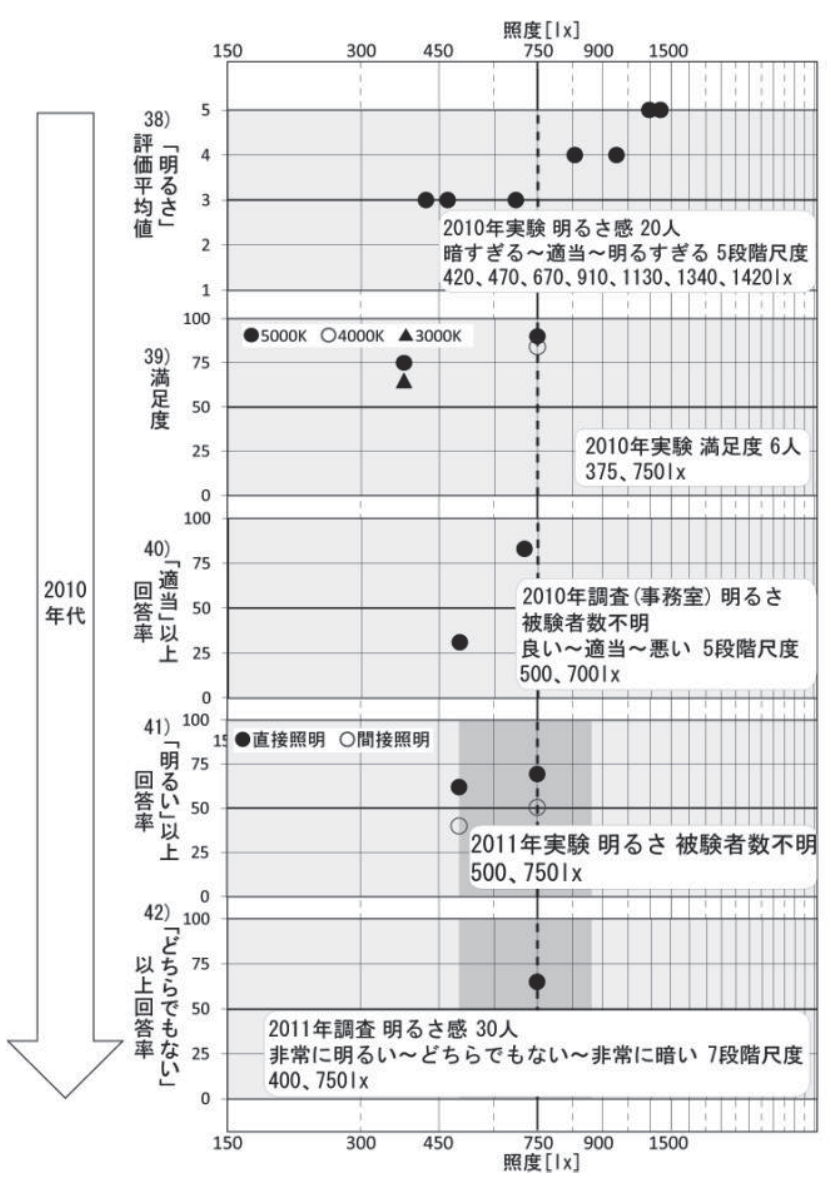

図 6 各研究結果の年代別比較 (2010 2011)

しかし 1980 年の文献 22)から評価が下がり始め、1981 年の文献 22) では 3201x で否定側の評価となっている。これ以降は文献 29)、文 献 31)、文献 33)で 250 3501x を評価している事例が見られるが、 1995 年の文献 34)以外は全ての事例で否定側の評価となった。図 1 でも 1958 年の 25 パーセンタイル值を最後に $3001 \mathrm{x}$ 以下の照度は全 く見られず、遅くとも 1981 年頃には要求が $3001 x$ より高くなって いると考えられる。

2)5001xに関して

1964 年から 2009 年までの JIS 推奨照度、2011 年からの JIS 下 限值である 500lx 付近の照度に着目する。450 5 50lx の照度は 1983 年から 2011 年までの文献 23)、文献 25)、文献 30)、文献 32)、文 献 33)、文献 36)、文献 37)、文献 38)、文献 40)、文献 41)の 10 の 事例で見られる。1964 年から 46 年間 JIS 推奨照度であったために 様々な事例で $5001 \mathrm{x}$ の評価は行われている。しかしその評価を見る と 1994 年の文献 30)で初めて否定側の評価となり、以降は文献 33)、 文献 37)、文献 40)、文献 41)の事例で否定側の評価を確認できる。 文献 31)や文献 35)、文献 41)など、5001x 未満の照度でも肯定側の 評価を得ている事例も散見されるが、図 1 でも 1994 年を最後に 25 パーセンタイル值でも $5001 \mathrm{x}$ 以下の照度は見られず、照度実態の上 昇とともに執務者の要求が上昇し、5001x より高い照度が求められ るようになったと考えられる。

3)7501xに関して

1979 年から 2009 年までの JIS 上限值、2010 年からの JIS 推奨 照度となっている $7501 \mathrm{x}$ 付近の照度に着目する。現在の JIS 推奨照 
度から JIS 上限值となっている 750 1000lx の照度は 1975 年から 2011 年までの文献 18)、文献 20)、文献 21)、文献 22)、文献 23)、 文献 25)、文献 26)、文献 27)、文献 28)、文献 30)、文献 31)、文献 32)、文献 33)、文献 34)、文献 37)、文献 38)、文献 39)、文献 41)、 文献 42)の 19 の事例で見られた。19 の事例中否定側の評価となっ たのは 1990 年の文献 27) と 1996 年の文献 33)のみであり、それ以 外は全て肯定側の評価となった。750〜10001x の照度はかなり幅広 い年代で実測された值であったが、少なくとも $7501 \mathrm{x}$ であれば安定 して肯定側の評価を得られている。

\section{3-3 考察}

屋内照明基準が制定された 1953 年から 2013 年までに行われた実 際のオフィスでの実態調査と、オフィスを想定した空間での印象評 価実験の事例を収集し、照度と評価の対応が見られるデータを読み とった。その結果、1981 年から徐々に 3001x と 5001x の評価が低 くなっていったことから、明るさを上げたいという要求が高まった ことがわかった。一方で、7501x に対寸る評価は全年代を通して変 わっていない。また、2 章で高照度の時代とした 1955 年から 1979 年にかけては、JIS 照度基準範囲内で肯定側の評価を得た事例が多 いことから、高照度環境が執務者の要求を過剩に引き上げる訳では ないといらことが考えられる。従って、要求される照度には範囲が あり、上限值は $7501 \mathrm{x}$ 付近で変わらないものの、下限值が徐々に高 まっていることが予想される。しかし、図 1 より 1990 年代後半か ら 500lx で設計されたオフィスそのものが減少していることから、 750lx という照度への慣れによる可能性もある。また、机上面照度 750lx が一貫して肯定側の評価であるとしても、一方でそれより低 い值にも拘らず肯定側となっている事例もある。単なる照度だけで はなく、空間全体の輝度分布も踏まえて設計するなどの対策を打つ ことで、机上面照度は $750 \mathrm{~lx}$ 以下でも快適な光環境を構築できる可 能性はある。

\section{4 まとめ}

オフィス照明環境の再考のための基礎的な知見を得るため、JIS 照度基準の前身となる屋内照明基準制定以降のオフィス照度の実態、 オフィスの明るさに対する執務者評価の 2 点について文献調查を行 った。その結果、日本のオフィスにおける照度は 1950 年代以降上 昇し、1970 年代には JIS 照度基準を大きく上回る高照度の事例も 多く見られた。1980 年以降オフィス照度は低下し、JIS 照度基準範 囲内の照度となった。1990 年代以降のオフィス照度は、1970 年代 から 1980 年代に見られたような 1000lx 近くの值にはならず、ほぼ JIS 照度基準範囲内に存在していた。この傾向は 2010 年代まで継 続していた。

一方、照度に対する執務者の評価は、文献 15) と文献 16)に見られ る同水準の照度に対する評価の低下から、1950 年代から 1960 年代 にかけての照度への要求水準の上昇が考えられる。また、1970 年代 には対応する研究がないため確認できないが、300lx 付近の照度へ の否定的評価が 1981 年の文献 22)以降で確認されはじめた事から も、1950 年代から 1980 年代にかけて照度への要求水準の上昇が続 いていたと推察される。そして、1970 年代までは JIS 照度基準範 囲内の照度でも肯定側の評価は得られていたが、1980 年代になると JIS 照度基準範囲内の照度で否定側の評価となる研究事例も現れ始
めた。この理由は、照度は高ければ高いほど視力がよくなり、物が 見や寸くなるため、照度が高いことが望ましいとされている ${ }^{43)} と$ からも、それまでの照度の実態の上昇により、執務者の要求水準を 引き上げた可能性がある。なお、 3 章の調査では回答者の年齢まで は言及しなかったために明確な関連があるかは不明だが、この半世 紀の間に、近距離視力が低下し、小さなサイズのランドルト環の読 み取りにもより高い照度が必要となることの多い ${ }^{44) 45)} 45$ 歳以上の 労働者の割合が増加したこと ${ }^{46)}$ も理由の一つであると推察される。 また、別の理由として 1970 年代の高照度環境への慣れの可能性も ある。

本研究では 750lx で執務者の評価は肯定側になるという結果とな ったが、肯定側の評価となる照度の最小值については、具体的な数

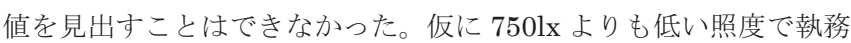
者から肯定側の評価を得られるのであれば、執務者の評価という観 点から言えば設計照度は $750 \mathrm{~lx}$ 以下に下げられる可能性がある。一 方、本研究では執務者の「半数」以上が肯定側の評価を得ていれば 肯定側の評価と定義したが、社会的な合意を得た照度の基準を見出 すには、執務者の何％が肯定的に捉える照度にすべきかという点も 検討が必要であろう。

本研究においては、オフィス照明環境の中でも特に照度に焦点を 当てて調查を行った。今後の課題としては、VDT 作業の増加をはじ めとする視作業の変化に伴い、机上面照度そのものの必要性は低下 しており、空間を構成する䨌囲気としての明るさ感を論じる場合に は、中村 477 のうに、今後は輝度の検討も必要と考えられる。また、 3 章の調查では東日本大震災が発生した 2011 年以降の文献を取り 扱う事ができず、震災という日本の電力事情を大きく変え得る出来 事による社会的な明るさへの要求の変化を確認できていない。震災 が与えた人々の感じるオフィスの明るさへの影響を考察するために は、今後更なる資料の蓄積が必要と考えられる。

本研究は科学研究費補助金（基盤研究（B)、課題番号 24360240 代表 : 岩 田利枝）による。

\section{参考文献}

1)(財)省エネルギーセンター：オフィスビルの省エネルギー パンフレット資 料、2009

2) 日本工業規格、JIS Z 9110:2010 照明基準総則 序文、2010

3)中村怜衣那、古賀靖子 : 国内外の屋内照明基準の歴史的変遷について、日 本建築学会九州支部研究報告第 51 号 pp93-99,2012.3

4)原口正平、ほか 4 名：オフィス照明環境の変遷に関する調査、日本建築学 会関東支部研究報告第 84 号( II),pp45-48,2014.3

5)総務省統計局：日本の長期統計系列、第 22 章 物価、主要品目の東京都区 部小売価格、http://www.stat.go.jp/data/chouki/22.htm、閲覧日 : 2015-3-27 6)総務省統計局 : 平成 25 年 家計調査年報、統計表、二人以上の世帯、時系 列支出、二人以上の世帯、

http://www.stat.go.jp/data/kakei/2013np/index.htm、閲覧日：2015-3-27 7)宗方淳 : オフィスの明るさ感と光環境満足度の関係の変化に関する考察、 日本建築学会大会学術講演梗概集,環境工学 I,pp501-502,2013

8)加納さくら、ほか 4 名：東日本大震災以後のオフィス照明の節電手法と執 務者光環境の変化、平成 26 年度照明学会第 47 回全国大会講演論文集,2014 9)北原理雄 :「住環境と景観」をテーマとした研究の動向に関する考察 -1975 ～1988-、第 24 回日本都市計画学会学術研究論文集,pp481-486,1989

10)Anca D. Galasiu、Jennifer A.Veitch : Occupant preferences and satisfaction with the luminous environment and control systems in daylit offices: a literature review、Energy and Buildings 38,pp728-742, 2006

11)中野淳太、田辺新一 : 半屋外環境の熱的快適性に関する考察 - 温熱環境適 
応研究の日本における温熱環境計画への応用とその課題-、日本建築学会環 境系論文集,第 79 巻,第 701 号,pp597-606,2014.9

12)E.Stamps : Demographic Effects in Environmental Aesthetics:A

Meta-Analysis、Journal of Planning Literature Vol.14、No.2 1999.11

13)(社) 照明学会：『照明年報』照明施設、照明学会雑 誌,Vol.49,No.7,pp378-393,1965

14）（社）照明学会：『照明年報』照明施設 5.2 事務所,銀行、照明学会 誌,vol67,No.8.p.381

15)薄山久夫 : けい光灯と眼に関する調査研究(第 1 報 : 銀行、百貨店におけ る調查)、照明学会雑誌,Vol.39,No.12,pp467-474,1955

16)江川隣之介、ほか 9 名：ビルディング照明の実態調査、照明学会雑 誌,Vol.46,No.12,pp601-606,1962

17)江川隣之介、ほか 8 名：ビルディング照明の実態調査、照明学会雑 誌,Vol.51,No.4,pp209-218,1967

18)佐土根範次、ほか 7 名 : オフィスビルにおける物理的環境の実態調查、照 明学会雑誌,Vol.59,No.10,pp20-26,1975

19) 太刀川三郎、ほか 11 名：ビルディング照明の実態調査、照明学会雑 誌,Vol.59,No.2,pp86-94,1975

20)安富重文、他 4 名 : 高層オフィスビル照明と居住性に関する調查、照明学 会雑誌,Vol.59,No.11,pp p552-557,1975

21)杉本賢：照明環境要素の生体への影響に関する研究-照度と生理的負担の 関係(その 1)、照明学会雑誌,vol.64,No.4,pp178-182,1980

22)杉本賢：照明環境要素の生体への影響に関する研究-照度と生理的負担の 関係(その 2)、照明学会雑誌,vol.65,No.4,pp171-175,1981

23)阿部隆ら、ほか 2 名 : 省エネルギー化を計った建物における照明設備その 3 -在室者の照明環境に対する意識調査、照明学会第 16 回全国大会講演論文 集,vol.67,p161-162,1983

24)竹ノ谷英俊、ほか 2 名: 事務所建物の室内環境に関するアンケート調査、 日本建築学会大会学術講演梗概集,pp665-666,1985

25)鹿島昭一、ほか 4 名：一般事務室の実態調査に基づく照明環境評価 室内 照明環境設計に関する実証的研究 その 1 , 日本建築学会計画系論文報告 集,No.365,pp30-39,1986.7

26)吉川松喜、ほか 3 名:オフィス環境改善手法の評価に関する研究(その 2) 心 理寮・物理量の関係の分析と改善手法の評価、日本建築学会大会学術講演 梗概集 D 環境工学,pp101-102,1989

27)大和田峰夫、ほか 2 名: オフィス環境と執務者の疲労に関する調査研究(そ の 1)-物理環境測定及び環境評価の結果と考察-、日本建築学会大会学術講 演梗概集 D 環境工学,pp113-114,1990

28) 五十嵐直治：オフィス照明環境の居住性調査、照明学会 誌,Vol.74,No.1,pp40-45,1990

29)山岸明浩、ほか 4 名 : 事業所室内環境評価に関寸る研究(その 2)-部門別 · 時刻別室内環境評価と物理量-、日本建築学会大会学術講演梗概集 D 環境 工学,pp99-100,1990

30)当摩昭子、佐藤仁人：執務空間における視環境の生理・心理的影響(その 2)。心拍数、脳波、主観的評価と照度との関係、日本建築学会大会学術講演 梗概集 D 環境工学,pp1205-1206,1994

31)村井卓生、ほか 2 名：人間の心理・生理・行動指標によるオフィス光環境 評価の一考察、照明学会第 28 回全国大会講演論文集,Vol.79,p196,1995

32)佐藤仁人、ほか 3 名: 執務空間における照度の生理心理的影響(その 2) 心 理的指標への影響及び生理 - 心理的指標相互の関係、照明学会 誌,Vol.80,No.6,pp331-338,1996

33)木村修、酒井しずか：タスク・アンビエント照明の事例とその評価、照明 学会第 29 回全国大会講演論文集,Vol.80,pp365-366,1996

34)藤田茂明、ほか 4 名：タスク・アンビエント照明の快適性とエネルギー評 価(その 2) 長時間の執務における照度の影響、日本建築学会大会学術講演 梗概集 D-1 環境工学 I ,pp365-366,1998

35)渡部耕次、ほか 5 名：タスクアンドアンビエント照明方式を用いた低照度 照明環境実現の可能性に関する研究、照明学会第 31 回全国大会講演論文 集,Vol.82,pp146-147,1998

36)竹村智明、他 4 名：タスク・アンビエント照明の快適性とエネルギー評価 (その 4) 行為の内容と適切な照度に関する調光実験、日本建築学会大会学 術講演梗概集 D-1 環境工学 I ,pp423-424,1999

37)望月菜穂子、井川憲男：オフィスでの行動に適した照明環境の研究-実大 空間における評価実験、照明学会第 34 回全国大会講演論文 集,Vol.85,p142,2001

38)五十嵐賢、ほか 2 名：アンビエント照明の低照度許容下限に関する調査、
日本建築学会大会学術講演梗概集 D-1 環境工学 I ,pp495-496,2010 39)割田智裕、ほか 6 名：照度・色温度が知的生産性に与える影響の検討,そ の 2 作業効率及び満足度、疲労度の関係、日本建築学会大会学術講演梗概 集 D-2 環境工学 II,pp1261-1262,2010

40)古屋誠二郎、高井啓明 : LED 照明を採用したタスク・アンビエント照明 によるオフィスの改修事例、日本建築学会大会学術講演梗概集 D-2 環境工 学 II ,pp1335-1336,2010

41)武田実可子、ほか 2 名 : 間接照明の実用化に向けた基礎実験 第 2 報 照度 測定およびアンケート調査による直接照明と間接照明の比較分析、日本建 築学会大会学術講演梗概集 D-1 環境工学 I ,pp471-472,2011

42)鹿毛比奈子、ほか 5 名：昼光利用とタスク・アンビエント照明を併用した 事務所空間における省エネルギー性能と光環境評価、日本建築学会大会学 術講演梗概集 D-1 環境工学 I ,pp499-500,2011

43）日本工業規格: JIS Z 9110-1979 照度基準解説、日本工業規格、pp1-3,1979 44)深澤暢子ら、ほか 2 名：高齢者の視力について-指標面の明るさの影響、

人間工学、Vol.35,p44,1999

45)佐川賢、ほか 2 名: 年代別視力のデータベースと日本語文字の最小可読閾、 照明学会第 35 回全国大会講演論文集、Vol.86,p166,2002

46)総務省統計局：労働力調査、長期時系列デー夕、就業者【年齢階級(10 歳 階級)別】、http://www.stat.go.jp/data/roudou/longtime/03roudou.htm、閲 覧日：2015-3-27

47) 中村芳樹 : シミュレーションを用いた次世代オフィス照明の設計技術、照 明学会誌,vol.96,No.9,pp624-630,2012

48)照明学会 : オフィス照明の実際 研究調査委員会報告書、2002

注

注 1)今回の調査で収集した事例は、建築設備士より 217 件、新編照明のデー タブックより 38 件、照明学会誌より 229 件であった。これらに掲載され る事例は、各文献の出版時にその時代ごとの最先端、または優れた照明計 画の事例を紹介しており、これらは日本のオフィス照明を先導する立場に あると推察される。なお、1981 年と 1982 年の 2 年間については、本調査 では事例を収集できなかった。

注 2) 文献には照度が「水平面照度」、「机上面照度」、「照度」と様々な言い回 しで掲載されていたが、484 件全てオフィスにおける事例であったことか ら、「机上面照度」であると解釈し、照度データの読み取りを行った。

注 3)本研究において「事務室」として収集した照度データは「普通事務室」 を対象としており、製図室、設計室、銀行の営業室などは除外している。 従って、JIS Z 9110-1979 の照度基準範囲は事務室(b)の值を JIS Z 9110-2010の比較対象として取り扱っている。

注 4)類似する既往研究として、(照明学会発行「オフィス照明の実際 研究調 査委員会報告書」、2002) ${ }^{48)}$ の図 6.1 に、1944 年から 2001 年に竣工したビ ルの平均初期照度の変遷をまとめたものがあるが、同研究の 1965 年、1973 年の調査結果と本研究での調査結果には差異がある。この理由としては、 本研究と既往研究の照度データ収集方法の違いが考えられる。本研究にお いて照度データ収集に用いた文献に掲載された事例は、掲載基準までは不 明であったものの、学会誌に掲載するという名目上、その時代ごとのある 程度先駆的な事例であったと考えられる。一方、既往研究は一般的なオフ イスを対象とした全数調査に近い方法で照度データを収集している。以上 のような照度データ収集方法の違いから、本研究と既往研究の調査結果に 差異が生まれたと考えられる。

注 5)収集した事例数は 28 件であったが、文献 33)からは 3 件,文献 35) と文献 37)からは 2 件ずつのデータをそれぞれ読み取ったため、作製したグラフは 32 件となった。 


\title{
A STUDY ON THE CHANGES OF LIGHT ENVIRONMENT AND EVALUATIONS BY WORKERS IN JAPANESE OFFICE
}

\author{
Yuichi NARISHIMA ${ }^{* 1}$, Jun MUNAKATA ${ }^{* 2}$, Toshie IWATA *3, \\ Tomoko TANIGUCHI ${ }^{* 4}$ and Etsuko MOCHIZUKI ${ }^{* 5}$ \\ ${ }^{* 1}$ Asahi Kasei Homes Co./Former Grad. Stud., Chiba Univ., M.Eng. \\ *2 Prof., Grad. Sch. of Eng., Chiba Univ., Dr.Eng. \\ ${ }^{*} 3$ Prof., Fac. of Eng., Tokai University, Dr.Eng. \\ ${ }^{*}$ Grad. Sch. of Sci. and Tech., Tokai Univ., M.Eng. \\ ${ }^{*}$ Prof., Fac. of Eng., Chiba Inst. of Tech., Dr.Eng.
}

The importance of saving energy in Japanese office is more and more increasing after the shutdown nuclear power plants caused by the great east Japan earthquake. As one of the method of saving energy, it is considered to be valid to reduce illuminance in office. Japanese recommended level of illuminance in office is $750 \mathrm{~lx}$, which is higher than those of foreign illuminance level. In order to reconsider the level of illuminance of Japanese Office environment, two kinds of literature review were conducted to get knowledge how the lighting environment as well as subjective evaluation about it has been changing in Japan.

Firstly illuminance's data of 484 offices which had been built after 1953 were collected. From these data, median, 25 percentile, and 75 percentile of illuminance in each year were indicated. In the last over half century, the illuminance of office environment have been increasing along with the recommended level of illuminance of JIS. Before 1980s, the actual illuminance level of Japanese office was higher than the recommended level of JIS. However, after 1980s, actual illuminance level was suddenly decreasing because of growing energy saving consciousness with oil shock. Today, it becomes to be settled on or less than the recommended level of JIS standard.

Secondly, to research the transition of subjective evaluation of illuminance, 28 study articles and theses published in the last over half century were collected. From those studies data about the relation between subjective response and illuminance was extracted, and finally 32 graphs were drawn with same format. The transition of the subjective evaluation of illuminance were researched by arranging these graphs by time series. As a result the subjective evaluation of illuminance also have been changing since 1950s. Before 1970s, people satisfied lighting environment of less than $300 \mathrm{~lx}$, and people became to be unsatisfied of $300 \mathrm{~lx}$ after 1980s. On the other hand, illuminance level of 750 lx has been evaluated positive consistently since 1970s.

Actual illuminance level of Japanese office and the brightness which workers want to was gradually rising from 1950 s to 1980 s. After 1980s, actual illuminance level was decreasing because of growing energy saving request caused by the oil shock, though the lower limit of required brightness was still rising from 300lx to 500lx. On the other hand, illuminance level of 750lx has been evaluated positive consistently. Because sense of brightness is decided by not only illuminance but also luminance distribution of the space, considering both illuminance and luminance distribution of the space, workers may be satisfied with the illuminance under 750lx. 